\title{
カゼイン水解乳栄羪中にビタミン $\mathrm{K}$ 欠乏症を発症した$$
\text { 牛乳アレルギーの3 乳児例 }
$$

\author{
(1989年1月16日受付) \\ (1989年6月 7 日受理) \\ 下葉市立海洪病院小科

池上宏 黑 崎知道鳥羽剛 \\ 宮城裕之桜井信清
}

Key words : Casein hydrolysate milk, Cow milk allergy, Vitamin K deficiency

\section{要旨}

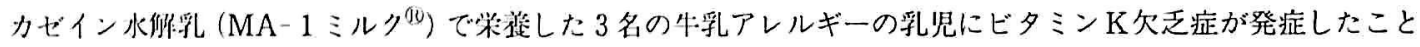
を報少した原国はがゼイン水解乳中のビタミンK浱度が低いためと思われた。このミルクで栄荃される乳児には， ピタミンKの補扎による子防が必要である。

はじめに

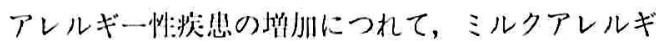

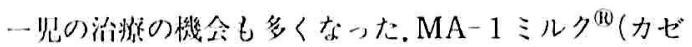

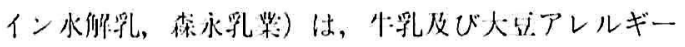
に対して们であることからしばしば使用されるが， そこに怠まれるビタミンKが㮌めて少ないことは，良

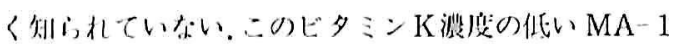

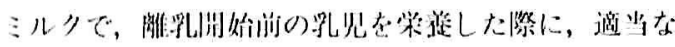

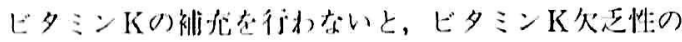

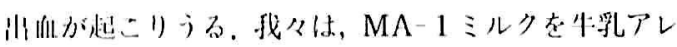

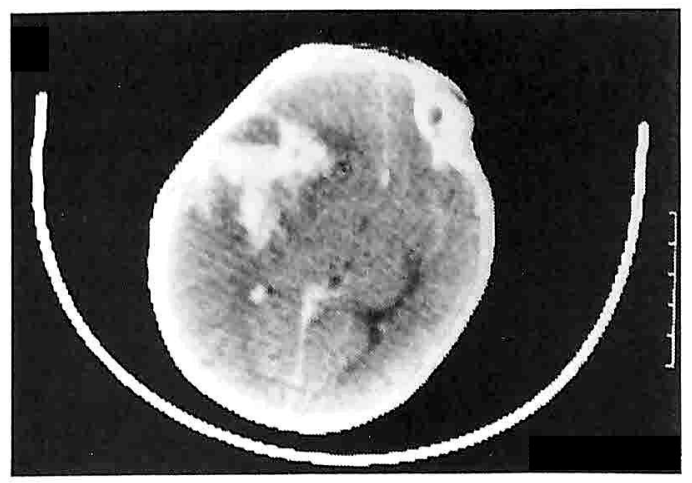

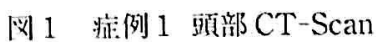

ルギー児に用いた結果，頭蓋内出血を起こし，不幸な 転帰をとった旭中央病院の 1 例と自験例の 2 例を報告 し，小児アレルギー診療の現場に注意を喚起したい．

\section{症例}

症例 1 . 生後 2 个月女児. 昭和 56 年12月, 生後 1 力 月半の洔，粘液を混ずる激しい下痢にて旭中央病院小 睍科に入院した。調整乳による 2 回の誘発テストと MA - 1 ミルクの有效性から,牛乳アレルギーと彰断された (表 1)。退院して10日目, MA-1 ミルクに変更して約 1 ヶ月後の昭和57年 2 月 5 日に, 嘔吐, 顔面萑白, 哺 乳力低下，さらに右半身痤戀をきたして再入院となっ た. 入院時, 赤血球約 270 万程度の貧血があり，採血部 位の止血が㜀難であった（表 2 ）。頭部 CT-Scan（図 1）では，左半球に実所から脳室にかけて広沉な出血 を認めた。 ビタミン $\mathrm{K}_{2}$ 投与, 輸血を行うも，一般状態， 呼吸状隹が悪化し，脳外科転科後に死亡した，凝固障 害をきたす基礎的疾患がなく旰障害もないことから， ビタミン $\mathrm{K}$ 欠乏による出血が最も疑われた。

症例 2 . 生後 2 个月男児. 生後より調整粉乳にて栄 善していたが, 生後 1 力月より，水様性下脷が 1 日 12 回位続くため, 生後 1 力月半に近医の指示で大豆乳に 変更した。大豆乳に変更しても軟便が 1 日10回以上, 嘔吐も $4 \sim 5$ 回で体重增加不良もあるため, 昭和 60 年 
3 月, 紹介されて当科入院となった。入院時，中等度 の脱水症, 腹部膨満, 全身の湿疹が認められた。両親 が共に小児期に気管支喘息という家族歴を有し，患児 の入院時検查 (表 3) から, IgE 高値, IgE RAST で は牛乳と大豆が疑陽性であり，牛乳及び大豆アレルギ 一と診断した，誘発テストは施行しなかったが，MA1 ミルクで経口哺乳を開始したところ，下琍は改善し 体重増加も順調であったため, MA-1 ミルク開始後 1 日目に退院とした，ところが，帰宅直後より悬出血が 出現し翌朝まで持続するため再入院となった，再入院 時の検查（表 4) では，明らかなビタミン $\mathrm{K}$ 欠乏性の 凝固障害を認めた。ビタミン $\mathrm{K} の$ 投与と少量の輸血に より，䊆出血は短時間の間に止血した(表 5 )。頭蓋内 出血の合併はなかった，その後， 2 週間に 1 度の間隔 で, 外来にてビタミン $\mathrm{K}_{2}$ シロップ $2 \mathrm{mg}(0.3-0.4 \mathrm{mg} /$ $\mathrm{kg}$ ）を経口的に補立した，時々行った凝固検查では巽 常なく，離乳食の開始を機会にビタミン K 投与を中止 した.

症例 3 . 生後 1 力月女児. 生後より母乳で栄養して いたが, 生後13日に調整粉乳にしたところ, 嘪水状の 嘔吐となった。 その後も噴水状の嘔吐が続き, 生後 15 日には粘液便になったため, 生後16日に紹介されて入 院となった（昭和61年 9 月）。入院時の検查（表 6 ）で は, IgE 低值, IgE RAST でも牛乳・大豆とも陰性で あったが, 父親が小児期気管支喘息とスギ花粉症，母 親がスギ花粉症の家族歴を持ち, MA-1 ミルクが有効 であったことから、牛乳アレルギーの疑いと㟝断した， はじめ母乳と MA-1ミルクの混合としたが, 退院後便 に少量の血液が混入するという訴えがあるため，母乳 の影響を考え MA-1 ミルク単独の栄菁とした(生後 1 カ月 3 日). その後血便はみられず順調に体重も增加し た.ビタミン $\mathrm{K}_{2}$ は入院時投与し, 以後ビタミン $\mathrm{K}_{2}$ シロ ップ $2 \mathrm{mg}(0.4-0.6 \mathrm{mg} / \mathrm{kg})$ を 2 週に 1 回の間隔で経 口投与した，MA-1 ミルクを開始して約 1 ケ後 (牛 後 1 カ月 16 日), 外来で採血したところ, 採血部位が止 血困難であり，血液凝固検査（表 7 ）でビタミンK欠 乏性の凝固障害が認められた。ビタミン $\mathrm{K}_{2}$ の筋注およ び経口投与により改善が得られ，(表 8 )その後しばら くビタミン $\mathrm{K}_{2} 0.5 \mathrm{mg} / \mathrm{kg}$ 前後を 1 週間に 1 回の間隔で 投与した。順調に経過し，離乳食が進んだところで投 与を中止した。

\section{考 察}

MA-1 ミルク栄盖中の乳児にビタミン $\mathrm{K}$ 欠乏症が発 症する原因の一つはミルク中に含まれるビタミンKが

表1。䅹例】のアレルギ一学的検雀

\begin{tabular}{|c|c|}
\hline $\operatorname{Ig} E$ & (RIST) \\
\hline $\operatorname{IgE}$ & $\begin{array}{l}\text { RAST } \\
\text { 牛峨 }\end{array}$ \\
\hline
\end{tabular}

便中好酸球 (t)

表 2. 禈例 1 ビタミン $\mathrm{K}_{2} 2 \mathrm{mg}$ 静注:, 輸血後の検岱所见

\begin{tabular}{|c|c|}
\hline 出血洔間 & 1 分 \\
\hline 凝固洔間 & 9 分 30 秒 \\
\hline WBC & $4,600 / \mathrm{mul}$ \\
\hline $\mathrm{RBC}$ & $344 \times 10^{4} / \mathrm{min}^{3}$ \\
\hline $\mathrm{Hb}$ & $9.8 \mathrm{~g} / \mathrm{dl}$ \\
\hline $\mathrm{Ht}$ & 32.496 \\
\hline PIt & $22.2 \times 10^{4} / \mathrm{mrn}$ \\
\hline GOT & $41 \mathrm{IU} / \mathrm{I}$ \\
\hline GPT & $85 \mathrm{IU} / \mathrm{I}$ \\
\hline LDH & $460 \mathrm{I} \mathrm{U} / \mathrm{I}$ \\
\hline
\end{tabular}

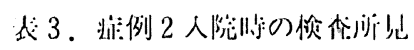

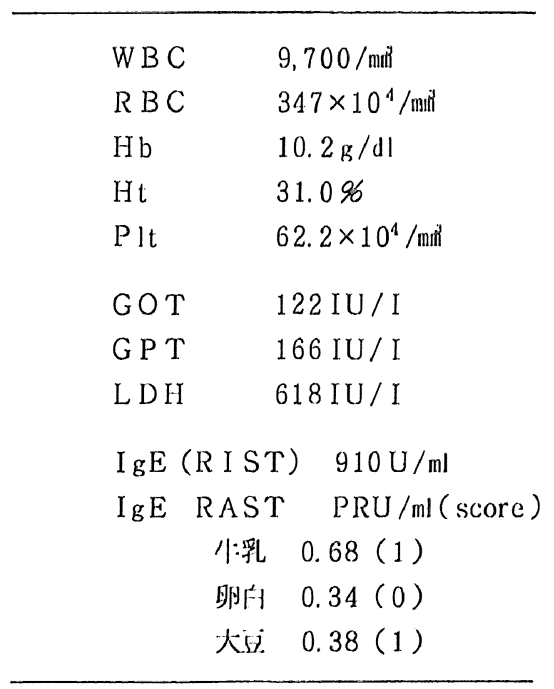

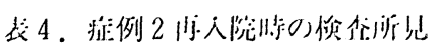

\begin{tabular}{ll} 
P T & $204.1 \mathrm{sec}$ \\
A P T T & $221.7 \mathrm{sec}$ \\
P I VKAII & $16 \sim 32 \mu \mathrm{g} / \mathrm{ml}$ \\
Hepapl astin & test $\quad<5 \%$ \\
\hline
\end{tabular}


表 5. 症例 2 ビタミン $\mathrm{K}_{2} 4 \mathrm{mg}(0.8 \mathrm{mg} / \mathrm{kg}$ ) 投与後(筋 注十静注) の凝固系㛟柤の推移

\begin{tabular}{|c|c|c|c|}
\hline \multicolumn{1}{|c|}{ 投与後の日数 } & 0 & 2 & 6 \\
\hline $\mathrm{PIVKA} \mathrm{II} \mu \mathrm{g} / \mathrm{mI}$ & $16 \sim 32$ & $4 \sim 8$ & $2 \sim 4$ \\
\hline Hepaplastin test & $<5 \%$ & $110 \%$ & \\
\hline $\mathrm{PT} \sec$ & 204.1 & 11.2 & 11.7 \\
\hline $\mathrm{APTT} \sec$ & 221.7 & 27.3 & 32.9 \\
\hline
\end{tabular}

将 6. 症例 3 のアレルギー学的蚞査

\begin{aligned} & \hline IgE (RIST) $(10 \mathrm{U} / \mathrm{ml} \\ & \mathrm{IgE} \mathrm{RAST}($ score $) \\ &$ 牛乳 $(0) \\ &$ 卵白 $(0) \\ &$ 大豆 $(0) \\ &$ 便中好酸球 $( \pm) \\ &$\hline\end{aligned}

装 7 . 症例 3 外来での梌査所見

\begin{tabular}{ll}
\hline PT & $13.6 \mathrm{sec}$ \\
APTT & $39.4 \mathrm{sec}$ \\
P I VKAII & $16 \sim 32 \mu \mathrm{g} / \mathrm{ml}$ \\
Hepaplastin test & $27 \%$ \\
\hline
\end{tabular}

代 8 . 灿例 3 ビタミン $\mathrm{K}_{2} 5 \mathrm{mg}(1.2 \mathrm{mg} / \mathrm{kg})$ 投与後(筋

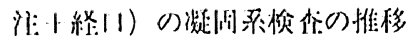

\begin{tabular}{|c|c|c|}
\hline 投与後の古数 & 0 & 3 \\
\hline PI YKA II $\quad \mu \mathrm{g} / \mathrm{mI}$ & $16 \sim 32$ & $<1$ \\
\hline Hepaplastin test & $27 \%$ & $88 \%$ \\
\hline $\mathrm{PT}$ & 13.6 & 10.8 \\
\hline APTT sec & 39.4 & 31.7 \\
\hline
\end{tabular}

少ないことである、MA-1 ミルクは，カゼイン, $\beta$ ラ クトグロブリン， $\alpha$ ラクトアルブミン，牛血清アルブ ミンを除上して抗原性を低くした牛乳及び大豆アレル ギーのための治泳乳である。治療上の理由から，油脂 として大泣油が使えず、サフラワーや梛子の油が用い られており，このためにビタミン $\mathrm{K} の$ 含有量が極めて 低いとされる。最近の测定法（HPLC法）では，母乳 中のビタミン K濃度が $0.5 \mu \mathrm{g} / \mathrm{dl}$ 前後であるのに対して, MA-1 ミルクでは，测定感度の $0.26 \mu \mathrm{g} / \mathrm{dl}$ 以下である
という．ピタミンK濃度の低い母乳に比べてもかなり 低い。

ミルクを哺乳する乳児の儧から問題をみると，共通 するのは 3 例と寻生後1 2力月の離乳前という事であ る。カゼイン水解乳におけるビタミンK欠乏症の唯一 の報告例である江原らの例"1は生後58日である。離乳前 にMA-1 ミルク単独で栄養するとビタミンK欠乏症を 発症しやすいようだ。その理由として，離乳前のこの

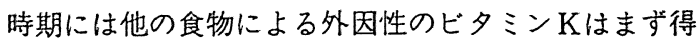
られないし，腸内細菌によるビタミン Kの十分な産生 も期待出来ない。さらにこのような乳児はミルクアレ ルギーのために栄養状態が悪く，すでに潜在的なビタ ミンK欠乏症に宿っている可能性等があげられる。こ のような状態の乳児を適当なビタミン Kの補充なしに MA-1 ミルクで栄養することは，ビタミンK欠乏症を 誘発することから，甚だ危険であると言えよう。

ビタミンKの投与については，未だ症例の䅪み重ね が少なく，安全で確実な方法を述べることは難しい。 症例 2 と症例 3 のビタミン $\mathrm{K}$ の投与にあたっては, 阿 部2の報告に抢ける大豆乳中のビタミン K濃度を参考に した。ビタミンK濃度の高いと言われるボンラクト 2 週間分に含まれるビタミンKの1.5～2 倍程度を 2 週間 に 1 度の割合で経口投与した（現在の測定法では数倍 と思われる). 症例 2 では，莮出血後前記の量で無事に

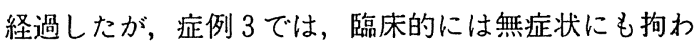
らず血液凝固検查では異常を示した。ニアミスであっ た。当洔，患児の栄荃状態は良好で吸収障害を疑わせ るような下痢はなく，十分量と思えたビタミンKの投 与でも発症したことから，量的な問題よりむしろ投与 間隔に問題があると思われた. MA-1 ミルクではない が, 舟乳栄養例について, 白幡3)らは, へパプラスチン テストが $40 \%$ 以下であると，ビタミン Kの投与間隔が 10日間でも危険な例のあることから，週に 1 回 1 3 $\mathrm{mg} / \mathrm{kg}$ を投与すべきと述べている.これらのことやプ ロトロンビンの半減期が $3 \sim 4$ 日であることを参考に すると、離乳前の乳児に MA-1 ミルクを使用する際は， 投与間隔により留意し,ビタミン $\mathrm{K}_{2}$ を週に 1 回 $1 \mathrm{mg} /$ $\mathrm{kg}$ 程度，投与するべきと考える。

ところで，ビタミンK欠乏性出血の重篤さや外来で の凝固検査の負担の事などを考えると，患児にとって 最も確実で負担のない方法はミルクへのビタミン $\mathrm{K} の$ 直接添加であろう。しかしながら，現状ではビタミン Kは『食品衛生法施行規則』及び『食品, 添加物等の 規格基準の定めるところ』(厚生省)における食品添加 
物に含まれておらず，ミルクへの直接添加が認められ ていない.しかし、ひとたびビタミン $\mathrm{K}$ 欠乏性出血が 生ずれば，不幸な結果となるやもしれないので，安全 にMA-1 ミルクを使えるように,ビタミンKの直接添 加が認められるべきと考える.ビタミン Kのミルクへ の直接添加は世界的趋勢と聞く。我々はこれら 3 例の 経験を通して, 食品行政上の改善を切望する次第であ る. (貴重なデータと御助言を頂いた森永乳業 川瀬興 三氏に深謝致します.)
文献

1）江原弘佳・根岸和子・富所隆三・小栗政丈：力ゼ

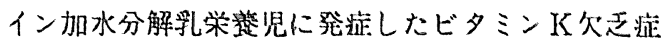
の1例，小児科臨床，35(6)：114-146，1982.

2 ) 阿部知子：大豆乳とビタミンK久立痛，小児科， 22(2): 125-132, 1981.

3 ）白幡 䧔, 中村外士雄，朝倉昭雄，山田来不雄，宝 地良和, 目黑 篦: 幼若乳睍の顽灌内出血 乳呪特 発性ビタミン K欠穴乏性出血症に関する最近の颜题, 産媕人科・新生児血液, 6(1)：14-21，1982.

\section{CASE REPORT OF 3 INFANTS WITH COW MILK ALLERGY AND VITAMIN K DEFICIENCY DURING CASEIN HYDROLYSATE MILK FEEDING}

Hiroshi Ikegami"), Tomomichi Kurosaki ${ }^{11}$, Tsuyoshi Toba'), Hiroyuki Miyagii' and Nobukiyo Sakurai ${ }^{2)}$

1) Department of Pediatrics, Chiba Municipal Kaihin Hospital

2) Department of Pediatrics Asahi General Hospital

We report vitamin $\mathrm{K}$ deficiency in 3 infants with cow milk allergy receiving a casein hydrolysate milk (MA -1 milk ${ }^{\circledR}$ ). Low vitamin $\mathrm{K}$ content of casein hydrolysate milk was considered the cause of the vitamin $\mathrm{K}$ deficiency. Vitamin $\mathrm{K}$ prophylaxis is therefore necessary in infants receiving this milk. 